\title{
Comments
}

\section{THE SECOND CONFLICTS RESTATEMENT OF TORTS:}

\section{A CAVEAT}

\section{INTRODUCTION}

Although most conflict of laws scholars agree that there is a need for change in the choice of law rules, there is a wide divergence as to exactly what changes should be made. ${ }^{1}$

In the past much emplasis has been put on simplicity and predictability. ${ }^{2}$ The first Restatement of the Law of Conflict of Lawes, based on the doctrine of "vested rights,"3 exemplified that approach. ${ }^{4}$ While this doctrine, particularly in the tort field, continues to lave some vitahty in the courts, ${ }^{5}$ and a few writers continue to favor it, ${ }^{6}$ almost thirty years of experience under the first Restatement has unquestionably vindicated those who lave opposed it. ${ }^{7}$

The American Law Institute is in the process of preparing a second Restatement. Its tentative draft on contracts purportedly abandoned the "vested rights" doctrine and substituted the concept of the "most significant relationship," a choice which immediately met with a great deal of criticism from a host of writers. ${ }^{9}$ Recently, the tentative draft on torts has also adopted the "most sigmificant relationship" concept.10

It is the purpose of this comment to demonstrate that this concept is unsatisfactory as a choice of law rule in tort cases and to urge the American Law Insti-

${ }^{1}$ See, e.g., EHRENzwEIG, Conflict of LAws 309-69 (1962) [hereinafter cited as Treatise] ; Cavers, The Two Local Law Theories, 63 HaRv. L. Rev. 822 (1950); Currie, Notes, Methods and Objectives in the Conflict of Laws, 1959 DUKE L.J. 171.

2 See, e.g., 3 Beale, Conflict of Laws 1967-69 (1935); Goodrich, Confutct of Laws (3d ed. 1949).

3 The vested rights doctrine functions in the field of choice of law as a counterpart to a theory of super-national judicial jurisdiction. Using a common denominator, it may be said that under the latter theory a foreign judgment is entitled to recognition if, and only if, a right is "vested" in the plaintiff by a foreign coutr "having jurisdiction" under a super-law. Similarly . . a foreign cause of action should be entitled to recognition if, and only if, it is "vested" under a foreign law "having jurisdiction" under a super-law.

Treatise $\S 4$ at 10.

4 The reference, in all cases, to one law, the law of the place of wrong, satisfies the desire for uniformity.

5 See, e.g., Waynick v. Chicago's Last Dep't Store, 269 F.2d 322 (7th Cir. 1959); Poplar v. Bourjois Inc., 298 N.Y. 62, 80 N.E.2d 334 (1948); Annot., 77 A.L.R.2d 1266 (1961).

'See, e.g., Cheatham \& Reese, Choice of the Applicable Law, 52 Colum. L. REv. 959 (1952).

7 Treatise $\S 171$ at 453 . Cavers, supra note 1; Currie, supra note 1.

8 Restatement (Second), Confuict of Laws \$ 332b (Tent. Draft No. 6, 1960).

${ }^{9}$ See, e.g., Treatise 351-53, 463-64; Cavers, Re-Restating the Conflict of Laves: The Chapter on Contracts, XXTH CEnTuRY Compraratrve and Confuicts LaW 349 (1961); Currie, Conflict, Crisis and Confusion in New York, 1963 DUKE L.J. 1; Weintraub, The Contracts Proposals of the Second Restatement of Conflict of Laws-A Critigue, 46 Iowa L. Rev. 713 (1961).

10 Restatement (Second), Confutct of Laws (Tent. Draft No. 8, 1963). 
tute to reconsider its adoption of the concept. Part I of this comment will consider and critically analyze the development of the traditional choice of law rules in the conflicts law of torts. Part II will consider the "most significant relationship" concept and the Institute's tentative draft. In Part III two additional, and more promising, alternatives to the traditional rules will be discussed: In Part III A, Professor Currie's theory will be briefly examined; ${ }^{11}$ in Part III B Professor Ehrenzweig's theory will be critically analyzed.

\section{THE TRADITIONAL CHOICE OF LAW RULES}

\section{A. A Brief History of the Conflicts Law of Torts}

In his first edition of Commentaries on the Conflict of Laws, published in $1834,{ }^{12}$ Joseph Story espoused the theory that applications of foreign law were based soley on comity, and not on a set of rules requiring displacement of forum law by a "governing" foreign law. ${ }^{13}$ Since Story considered torts a branch of the law of remedies, 14 he did not treat the conflicts law of torts separately, nor did he consider torts an exception to the principle that remedies were subject to forun law. ${ }^{15}$ The concept of "governing rules" in the conflicts law of torts developed only after wrongful death liability appeared in 1846, creating an entirely new field for the application of conflicts law to tort problems.

Originally wrongful death statutes were, "presumably owing to judicial preference for the common law, ... treated as local and limited to domestic causes of action ...." However, the concept of "goverming rules" soon appeared in this area; an 1857 New York decision held that the New York statute did not apply to a Comecticut accident, reasoning that "whether an act or omission affords a right of action depends on the law of the place where it is done or omitted."1r Despite this apparent shift toward a "governing rule" concept, Field, in 1872, stated that it was a "well settled rule, founded on reason and authority ... that the lex fori . . . furnishes in all cases, prima facie, the rule of decision ...."18 Even as late as 1875, the Supreme Court of Wisconsin was able to

11 Currie's theory has been discussed in numerous articles. See, e.g., Ehrenzweig, Choice of Law: Current Doctrine and "True Rules," 49 CALIF. L. REv. 240 (1961) ; Hill, Governmental Interest and the Confict of Laws $-A$ Reply to Professor Currie, 27 U. CHr. L. REv. 463 (1960) ; Schreter, "Quasi Community Property" in the Conflict of Laws, 50 CaITF. L. REv. 306 (1962); M. Traynor, Confict of Laws: Professor Currie's Restrained and Enlightened Forum, 49 CaLrF. I. Rev. 825 (1961) ; R. Traynor, Is This Conflict Really Necessary?, 37 TexAS L. Rev. 657 (1959). Accordingly, greater attention will be given Professor Ehrenzweig's theory.

12 Story, COMIMENTARIES ON THE CONFutct OF Laws (1834).

13 See Ehrenzweig, The Lex Fori-Basic Rule in the Conflict of Laws, 58 Mica. L. REv. 637,666 (1960).

14 See Treatise $\$ 211$ at 542 .

15 See ibid.

16 Ehrenzweig, supra note 13 at 673. At this stage reference to foreign laws was not due to a theory of "governing rules," as is evidenced by the fact that forum common law was also preferred over foreign statutes. Id. at 673-74.

17 Vandeventer v. The N.Y. \& N.H. R.R., 27 Barb. 244, 246 (N.Y. 1857).

18 FIeld, OUTLINES OF AN INTERNATIONAL CODE 439 (1872). 
say that the rule that a personal injury action is governed by the law of the forum is "almost too familiar . . f for discussion or authority."10 But in 1880 the Supreme Court of the United States, in Dennick v. Railroad Co., ${ }^{20}$ held applicable the wrongful death statute of the state in which "a right of action has become fixed and a legal habihty incurred."21

Since the Dennick case American courts have had to contend with a general "rule" of the conflicts law of torts. ${ }^{22}$ The "rule" as expounded in the first Restatement owes its existence chiefly to Joseph Beale. Beale, applying the "vested rights" theory, developed the "rule" that torts are governed by the law of the "place of wrong." the following definition: "The place of wrong is in the state where the last event necessary to inake an actor hable for an alleged tort takes place."24 Beale, the reporter for the Restatement, explained this definition in these terms: "The place of wrong is the place where the person or thing harned is situated at the time of wrong." 25

The place of wrong has not always been defined as the place of harm; in the late 19th Century, the place of wrong frequently was defined as the place of conduct ${ }^{26}$ and this deffnition was adopted by an American court as late as 1918.27 The Restatement's place of harm rule, however, has been cited in the vast majority of the tort conflicts cases that have arisen in this country since its publication. ${ }^{28}$ To the extent that the courts almost unanimously have purported to follow the rule, it can be said to correctly reflect present law. Whether the results the courts have reaclied justify the rule as a statement of living law is another matter.

\section{B. Intentional Torts}

A discussion of the first Restatement's rule as it applies to intentional torts will be facilitated by an exanination of the rationale of both the place of conduct and the place of harm rules and an investigation of why the latter replaced the former.

The classic statenent of the rationale of the place of conduct rule is by Holmes in American Banana Co. v. United Fruit Co.:20 "the character of an act as lawful or unlawful must be determined wholly by the law of the country where the act is done .... For another jurisdiction, if it should happen to lay hold of the actor, to treat him according to its own notions rather than those

19 Anderson v. Milwaukee \& St. Paul Ry., 37 Wis. 321, 322 (1875).

20103 U.S. 11 (1880).

21 Id. at 18.

22 See TrEATISE $\$ 120$ at 344.

23 Beale, A Treatise on the Confutct of Laws or Private Internationat Law (1916). The "vested rights" theory was first developed on the continent and later expressed in England by Dicey. See generally, Dicey, A Digest of the LAW of ENGLAND with REFERENCE to the CONFITCT OF LAWS (1896).

24 Restatement, Conflict of Laws $\$ 377$ (1934).

252 BEALE, CoNflict of Laws $\$ 377.2$ (1935).

26 See Treatise $\$ 211$ at 546.

27 Connecticut Valley Lumber Co. v. Maine Cent. R.R., 78 N.H. 553, 103 Atl. 263 (1918).

28 See TREATISE $\$ 211$ at 545 .

29213 U.S. 347 (1909). 
of the place where he did the acts . . would be unjust ...."30 This lex actus rule is founded on the notion that the defendant, anticipating that his conduct would be judged only under the lex actus, quite possibly would have refrained from acting at all had he been able to foresee that another law would apply. ${ }^{31}$

The defendant's expectations govern his conduct only if that conduct involves conscious choice. Since it is meaningless to speak of conscious choice in cases of non-intentional acts, it appears that the rationale of the lex actus rule is applicable only to intentional torts, ${ }^{32}$ for only in these cases is intent material to liability. ${ }^{33}$ The presence of intent introduces an element of moral culpability; liability for intentional torts, therefore, has a substantial admomitory purpose. As Judge Wyzanski has put it, in a conflicts case involving the intentional tort of alienation of affections: "the principal reason why the state stamps conduct as wrongful is that so many people regard it as sinful ... as offensive to public morals. In such a case the compensatory element is of secondary consequence. ${ }^{234}$ In contrast, in cases of neghigence and strict liability intent is irrelevant; the predominant purpose for imposing liability is to compensate the plaintiff. ${ }^{35}$ Concern for the compensation of the plaintiff seems to require reference to a law not unfavorable to the plaintiff, rather than a law to protect a defendant who has no valid grounds for requesting protection. The rapid rise in importance of negligence and strict liability ${ }^{36}$ was a factor in the replacement of the lex actus rule (directed toward the primarily admonitory intentional torts) by the place of harm rule. ${ }^{37}$

Because the place of harm rule evolved to satisfy the needs of the plaintiff in cases of compensatory non-intentional torts and the place of conduct rule is designed to protect the defendant in cases of intentional torts, the Restaters' use of the place of harm rule as a general rule applicable to all torts might be viewed as an unwarranted attempt at uniformity. ${ }^{38}$ To insure that such a judgunent is not made too lastily, the application of the place of harm rule to concrete cases involving intentional torts must be discussed.

Suppose the defendant, a resident of New York, has deliberately and in person told the plaintiff, a woman whom he knew to be highly emotional, that her husband had been horribly mutilated in an accident, a statement which he $\mathrm{knew}$ to be false. The plaintiff as a result has suffered great mental distress, but no bodily harm. The plamtiff is a resident of Connecticut and the defendant made the false statement there. The plaintiff brings suit in New York, seeking

30 Id. at 356. This emphasis on fairness to the defendant is further demonstrated by the fact that it was some time after defenses based on the lex actus had been generally admitted that claims based on the lex actus were recognized. TREATISE $\$ 211$ at 543-44.

31 See 2 Rabei, The Conflict of Laws: A Comparative Study 251-54 (2d ed. 1960).

32 Willful or reckless conduct is included in the category of intentional torts.

33 PROSSER, TORTS $\$ \$ 6,7,33$ (2d ed. 1955).

34 Gordon v. Parker, 83 F. Supp. 40, 42 (Mass.), aff'd on other grounds, 178 F.2d 888 (1st Cir. 1949).

85 See TREATISE \$ 212; Ehrenzweig, The Place of Acting in Intentional Multistate Torts: Law and Reason versus the Restatement, 36 MINN. L. REv. 1, 2, 5 (1951).

30 Treatise $\$ 217$ at 569; Ehrenzweig, suppra note 35 at 1, 2. See 2 Rabei, op. cit. supra note 31 at 302 .

37 Ibid.

38 TrEatise $§ 217$ at 569 . 
to hold the defendant liable for the tort of intentional infliction of mental distress. Assume Connecticut allows recovery without proof of bodily harm; that New York does not. The Restaters would apply the "law" 39 of Connecticut, the place of harm, and the plaintiff might recover. This result seems acceptable. Since the place of harm and the place of conduct are the same, the defendant has not been treated unfairly. Moreover, the fact that the law of the defendant's residence does not see fit to admonish such acts should not mean that the defendant may enter another state and deliberately conduct limself there without regard to the law of that state. Had the conduct and harm both occurred in New York, the result (non-liability since New York would then be the place of harm) would still be acceptable. The result in such a case might be criticized if both the plaintiff and the defendant were residents of Connecticut, for in such a case Connecticut seems to have at least some "interest" in the application of its admonitory policy and clearly has an "interest" in the plaintiff's compensation. ${ }^{40}$ But simce the conduct occurred in New York, the principle of fairness to the defendant provides some justification for non-liability under New York law.

However, let us suppose another case. Assume that the defendant made the false statement over a teleplione in Connecticut and that the plaintiff heard the statement and suffered mental disturbance in New York. Both parties are residents of Connecticut, the forum. In such a case the application of the first Restatement's rule can lead to absurd results. No liability would result under the law of New York, the place of harm, but the law of Connecticut, the place of conduct, would call for liability. To prefer a New York non-liability rule over a Connecticut liability rule flies in the face of the admonitory policy of the forum without securing any justifiable protection to the defendant. Also, Connecticut's interest in compensating the plaintiff is defeated. If a foreign liability rule is preferred over a forum non-hability rule (as would be the case if the supposed laws of Connecticut and New York were reversed) the result is a denial to the defendant of the protection of the laws under which he acted. Although the admonitory policy of the foreign state would be furthered, that state has little interest in the non-resident parties.

Whatever the theoretical result under a literal apphication of the place of harm rule, it appears that American courts do not apply that rule in cases of intentional torts-certainly not to prefer foreign non-liability over forum liability when the forum is the place of conduct. ${ }^{41}$ Since the courts do not in practice

39 " $\mathrm{Law}$," if read literally, would include the conflicts law of the state referred to, creating renvoi problems. What is really intended is a reference to the rule which the foreign state would apply in a wholly domestic situation. See, RestateMrent, CoNfuict of Laws \& 7 (1934); CoOK, The logtcat and Legal Bases of the Confutct of Laws 19-34 (1942); Lorenzen, The Renvoi Doctrine in the Confict of Laws-Meaning of the "Law of a Country," in SElected ARTtCles on tHe Conplict of LAws 54 (1947).

$40 \mathrm{~A}$ forum state may have an interest in the application of its admonitory policy to one of its residents regardless of where the conduct occurred; such application may serve to deter such conduct in the forum state. A forum state has a definite interest in seeing that its residents are compensated for injuries suffered by them, if only to prevent them from becoming public charges. For a discussion of two theories emphasizing interest analysis see Part III of this comment, infra.

41 See Ehrenzweig, supra note 35 at 5-6 (asserting that actually preference is given to the lex actus); TREATISE $\$ 215$ (asserting, apparently after reconsideration, that the lex fori is preferred). 
reach the first Restatement's result, the place of harm rule is not valid and must be discarded as a "general rule" in all intentional tort situations. ${ }^{42}$

The void left by the rejection of the place of harm rule must be filled by some competing rule. Accordingly, a brief discussion of possible alternatives to the place of harm rule is in order. It should be recognized that intentional torts differ widely. Some, such as unfair competition, tend to resemble those nonintentional torts in which the compensatory element predominates ${ }^{43}$ Classification of such torts is difficult because liability results from an approximately equal concern for admonition and compensation. Therefore the following discussion is not to be interpreted as applicable to unfair competition or similar intentional torts in which admonition is not the primary element of liability.

As to the intentional torts in which the admonitory purpose of liability predominates, it is arguable that the lex actus rule should be applied. Here the policy of protection and fairness for the defendant is meaningful and can be viewed as outweighing the forum's admonitory policy when the foreign lex actus does not create liability. Also, it has been argued that the results actually reached by the courts in this area can be rationalized under a place of conduct rule. ${ }^{44}$ The first Restatement itself has recognized the applicability of the lex actus in the case where the defendant acts pursuant to a privilege conferred by the lex actus or under a duty imposed by the lex actus, ${ }^{45}$ but this exception to the place of harm rule does not cover the majority of intentional tort cases. ${ }^{46}$

Some difficulty in the application of a lex actus rule may arise, as in a case where the rule of a foreign lex actus would result in non-bability while there would be liability under the lex fori, the forum also being the place of harm. In this situation it may be more reasonable to allow the admonitory policy of the forum to predominate, especially where both plaintiff and defendant are residents of the forum, ${ }^{47}$ although the "fairness" argument still has justification. Since a lex fori rule appears reasonable in this situation and since it has been argued that the lex fori rule is consistent with the results actually reached by the courts in intentional tort cases, ${ }^{48}$ a general rule referring to the lex fori may be an acceptable alternative to the place of larm rule. One obvious advantage is the court's familiarity with the lex fori. Moreover, it seems equitable to apply the lex fori in those instances in which both parties reside in the forum and the forum is either the place of conduct or of harm. But if the defendant is not a resident of the forum and neither the harm nor the conduct occurred there, application of the lex fori would conflict with the primciple of fairness to the defendant.

42 Ehrenzweig, supra note 35 at 5-6.

43 See Treatise $\$ 212$.

44 Ehrenzweig, supra note 35 at 5 . See Rheinstein, The Place of Wrong: A Study in the Method of Case Law, 19 TuL. L. Rev 4, 30 (1944).

45 Restateasent, Confitct of Laws $\$ 382$ (1934).

46 Only if "privilege" is interpreted as being synonymous with nonliability could the Restaters' exception become instead the rule as regards intentional torts. Since the Restaters do not intend the "privilege" exception to be so comprehensive their exception is deficient.

47 A "public pohicy" consideration may be a factor in finding an exception to a general lex actus rule in cases where the forum is the place of harm. See 2 RABEL, op. cit. supra note 31 at 248-51; Ehrenzweig, supra note 35 at 5; Rheinstein, supra note 44 at 31 . See also TrEATISE $\$ 120$, explaining the public policy exception as a concomitant of "general rules" of conflicts law.

48 Treatise $\S 215$. 
It appears that there are valid objections to a choice of law rule which refers exclusively to either the lex actus or the lex fori in intentional tort cases. It has been suggested that the plaintiff should be allowed to choose between the two laws so that recovery will follow if either law creates liability. ${ }^{40}$ This theory is defective because it would abrogate the principle of protecting the defendant from hability under laws whose apphication he could not have foreseen. Apparently a general choice of law rule, workable in all intentional tort situations, is no more feasible than is a general rule applicable to all torts. ${ }^{50}$ A suggested alternative for conflicts cases involving intentional torts is a lex actus rule, witl certain specific exceptions as may appear necessary after further investigation. ${ }^{51}$ The Restaters, in their tentative draft on torts, recognize the distinction between admonitory and compensatory torts and seem to favor a lex actus rule for the former..$^{52}$ In any event, the first Restatement's place of harm is demonstrably inapplicable to intentional torts and thus unwarranted as a "general rule."

\section{Negligence and Strict Liability}

The majority of tort cases in the courts today are concerned with those liabilities in which intent is immaterial-negligence and strict liability. ${ }^{63}$ The most important negligence and strict liability cases are those seeking a just and reasonable allocation of losses caused by modern industrial society. ${ }^{54}$ Although perliaps avoidable in the specific instance, such losses are necessary by-products of an industrial society. Far from holding the entrepreneur morally blameworthy for the losses which result from his activities, society encourages these activities. ${ }^{.5}$ The liability imposed for these losses is closer to strict liability than to negligence liability and the policy justifying the liability is clearly aimed at compensating the plaintiff rather than admomshing the defendant. ${ }^{58}$ Although the place of liarm rule ostensibly was formulated with this in mind, ${ }^{67}$ the rule has serious disadvantages, even as apphied to compensatory tort habilities.

The first Restatement itself impliedly recognizes an exception to the place of harm rule in cases of wrongful death. It defines the place of wrong in such cases as the place where the imjury was inflicted on decedent, not the place of death or the place where the pecuniary loss to the plaintiff was caused ${ }^{88}$ This definition apparently is explained by the rationale that the plaintiff's right to sue is not based on the death itself, but on the causing of the death by the defendant. ${ }^{50}$ In taking this position, the Restaters have deviated from their "last event" definition of the place of wrong, since the last event necessary to make a defendant liable in

49 Coor, op. cit. supra note 39 at 345 .

50 Resort may have to be had to rules covering only the specific intentional torts in question, rules which can take into account the fact that the admonitory element in the tort of battery is much stronger in relation to its compensatory element than is the case in, for example, the tort of conversion.

51 Rheinstein's suggestions are along these general lines. See Rhemstein, stkpra note 44 at $30-31$.

52 Restatement (Second), Conflict of Laws $\$ \$ 379(3)$, comment $c$, 379i, 379j (Tent.

Draft No. 8, 1963).

53 See Ehrenzweig, Negligence without Fautr 2 (1951).

54 Id. at 21 ; Treatise $\$ 212$; Prosser, TORTS $\$ 28$ (2d ed. 1955).

55 TREATISE $\& 217$ at 569 .

66 Ehrenzwerg, Negrigence without Fault 17 (1951). Imposition of liability will, of course, also serve to encourage the entreprencur to keep the number of inevitable accidents at the lowest possible figure.

57 TREATISE $\$ 217$ at 569 . 
a wrongful death action is death itself. Whether the statute in question be a "survival" or a "death" act, the harm complained of is not the original injury but the death and its consequences..$^{60}$ Where enterprise liability is concerned, the emphasis on compensation would imply that if any one law must be applicable, it should be that of the "place of harm"- the place where the beneficiary of the cause of action suffered harm, ${ }^{61}$ not the place where harm occurred to the decedent. Thus, the first Restatement, in its treatment of wrongful death actions, does not properly deal with the concern for the plaintiff's compensation and is therefore deficient.

There is a more serious objection to the place of harm rule which concerns the basic purpose underlying enterprise liability. Though the place of harm rule evolved from concern for compensation of the plaintiff, a literal application of the rule can result in an unjustified denial of liability. This can be demonstrated by contrasting two hypothetical situations.

Suppose the plaintiff is injured in Utah, his domicile, by the consumption of contaminated food, prepared by the defendant in Nevada and distributed in Utah. Suppose the domestic law of Utah, the forum, would impose strict liability in such a case, while that of Nevada would require proof of neghigence. Simce Utah is the place of harm its law would apply under the first Restatement rule and the plaintiff would be able to recover without having to prove negligence. This seems a just result. The defendant cannot be heard to argue that because his conduct occurred in Nevada the law of Nevada should apply, since in most cases his conduct, being unintentional, would not have differed had he been aware that he would be judged under another law. A tenuous argument could be made that the defendant set up business in Nevada because he wished his conduct to create liability only if it should be found negligent. At least as realistic would be the counter-argument that when the defendant decided to engage in a business having interstate connotations he must have foreseen that instances might arise in which liability would be determined under the laws of other states. On the other hand, by the application of Utah law the plaintiff is fully protected and the loss is borne by the enterprise whose operations created the risk. The enterprise can be expected to anticipate a relatively stable number of such "accidents" and price accordingly so as to spread the cost among the general public. ${ }^{62}$

Suppose, however, that the defendant prepares food in Utah and distributes it in many states, including Utal and Nevada. The plaintiff, a resident of Utah, is sumg in a Utah court for an injury he suffered due to consumption of contaminated food whicl the defendant prepared in Utah, but which plaintiff consumed in Nevada. Assume, again, that the domestic law of Utah would hold the defendant strictly liable while that of Nevada would require proof of negligence. The Restaters would have the law of Nevada apply, Nevada being the place of harm, and would deny recovery unless negligence were proved. This result can be applauded only if one places a premium on restricting liability, a point of view

58 Restatearent, Conflict of Laws $\$ 391$, comments $a, b, c$ (1934).

50 See Vancouver S.S. Co. v. Rice, 288 U.S. 445,447 (1932), quoted by the Reporter of the Restatement, Professor Beale, in 2 Beale, Confuict of Laws 1306 (1935).

${ }^{60}$ See Prosser, Torrs $\$ 105$ at 709-16 (2d ed. 1955).

61 See Treatise $\S 211$ at 547 .

02 See concurring opinion of Traynor, J., in Escola v. Coca Cola Bottling Co., 24 Cal. 2d $453,462,150$ P.2d 436, 441 (1944). 
which, regardless of its intrinsic merits or demerits, is contrary to the basic policy of the forum, Utah. It is suggested that in this and similar situations a rigid application of the place of harm rule not only fails to promote affirmatively the policy of the forum with respect to enterprise liability, but irrationally and indefensibly defeats it. ${ }^{63}$

It is only natural that courts should seek ways to escape such absurd results, and in practice various devices have been utilized to that end. Courts have resorted to characterization of the action as one of contract rather than tort ${ }^{64}$ or one involving matters of procedure rather than substance ${ }^{65}$ in order to apply the lex fori or another law which permits a just result. The place of wrong has been localized ${ }^{66} \mathrm{~m}$ a state with a favorable law and resort has been made to the doctrine of renvoi ${ }^{67}$ in order to apply a law other than that of the place of harm. Public policy has been held to require application of the lex fori, ${ }^{08}$ as has failure to plead and prove the law of the place of harm. ${ }^{69}$

In conclusion, the first Restatement's place of harm rule, clearly indefensible as applied to intentional torts, is also unjustified as a "general rule" applied to compensatory torts.

\section{II}

\section{THE STATE HAVING THE "MOST SIGNIFICANT RELATIONSHIP"-THE "PROPER LAW" THEORY}

The "proper law" theory as a choice of law rule in contract cases has its origins in England: ${ }^{70}$ It lias long been accepted solely by the Commonwealth. The American Law Institute, however, in its contracts draft for the second Conflicts Restatement adopted the "most significant relationship" concept-virtually an alter ego of the "proper law" theory. ${ }^{71}$ And now the concept has been adopted in the torts draft for the second Conficts Restatement..$^{22}$ An analysis of the applicability of the "proper law" theory to torts will be facilitated by a discussion of the theory's operation in the conflicts law of contracts.

\section{A. Contracts}

The English rule is well settled: The validity of a contract is governed by its proper law, that is "the law, or laws by which the parties intended, or may fairly

63 See, e.g., Mason v. American Emery Wheel Works, 241 F.2d 906 (1st Cir.), cert. denied, 355 U.S. 815 (1957); Alabama G.S.R. Co. v. Carroll, 97 Ala. 126, 11 So. 803 (1892).

64 E.g., Levy v. Daniels' U-Drive Auto Renting Co., 108 Conn. 333, 143 Atl. 163 (1928).

65 E.g., Grant v. McAuliffe, 41 Cal. 2d 859, 264 P.2d 944 (1953). See Pcarson v. Northeast Airlines, 307 F.2d 131 (2d Cir. 1962).

60 See Treatise $\$ 215$.

67 Under the renvoi doctrine the conflicts law of the forum is treated as referring to the conflicts law as well as the local law of the foreign state. If that conflicts law refers to a law other than that of the foreign state, the forum follows the reference. TrEatuSE $§ 116$. See, e.g., Alaska Airlines, Inc. v. Stephenson, 217 F.2d 295 (9th Cir. 1954).

68 E.g., Loucks v. Standard Oil Co., 224 N.Y. 99, 120 N.E. 198 (1918).

69 E.g., Krasnow v. Nat'l Airlines, Inc., 228 F.2d 326 (2d Cir. 1955).

70 Dicey, Confrict of Laws 779-88 (7th ed. 1958) ; Mann, The Proper Law of the Contract, 3 INT's L.Q. 60 (1950); Morris, The Proper Law of a Contract: A Reply, 3 INT'L L.Q. 197 (1950).

71 The draft recognized that the two theories are virtually the same. RESTATEMENT (Second), Conflict of Laws $\$ 332$ (Tent. Draft No. 6, 1960).

72 See Restatement (Second), Conflict of Laws $\$ 379$ (Tent. Draft No. 8, 1963). 
be presumed to have intended, the contract to be governed ...."73 As this quote from the leading treatise indicates, the intention of the parties is the elusive quantity which the rule purports to vindicate. When the parties choose a law to govern their contract, the courts will give effect to that express intention, provided the law selected has a close factual connection with the case. ${ }^{74}$ When there is no express intention, the "proper law" theory purports to find an impled intention through an analysis and evaluation, from "social and economic points of view,"?5 of the laws of those places traditionally considered to have contacts with a contract. As envisioned, the theory enables proper weight to be attributed in a particular case to factors of constantly varying significance; the court will decide which law should govern the particular issue before it, rather than deciding which law governs the broad legal question involved. ${ }^{76}$ Without question, the "proper law" doctrine, in theory, is an attempt to break away from the rigidly mechanical approach of the "vested rights" theory. The "proper law" theory proposes needed and welcome flexibility and is at least a step in the right direction; unfortunately the theory fails to go far enough, since it offers insufficient gnidance for its use. ${ }^{77}$

Because of its conceded flexibility, the "proper law" theory is subject to attack by the proponents of simple and predictable choice of law rules. ${ }^{78}$ Such rules have been previously examined, and the narrow objections of the traditionalists must be discounted. While certainty, umformity, and predictability are clearly desirable goals, ${ }^{79}$ experience under the first Restatement has indicated that if we are to obtain rational results in conflicts cases, such goals can only be achieved gradually. ${ }^{80} \mathrm{~A}$ more valid criticism is that the "proper law" formula is circular. What is a proper law is the very question a choice of law rule must answer. ${ }^{81}$ Moreover, since it las never been clearly stated how the determination of the parties' unexpressed intention is to be made, the proposed analysis of the contacts in light of social and economic policy often may never take place. ${ }^{82}$

Like the "proper law" theory, the "most significant relationship" concept of the second Restatement's contracts draft provides for party autonomy ${ }^{83}$ - subject

73 DiCEY, CONFLiCT OF LAws 579 (6th ed. 1949).

74 See Mann, supra note 70 at 64-67; Morris, supra note 70 at 202-03. There is a dispute among the "proper law advocates" over the so-called "subjective and objective" theories of proper law. The "objective theory," which calls for an analysis of the "most significant connections," and urges that party autonomy is only one factor to be considered, has little support in the language of the cases. Mann, supra note 70; Morris, supra note 70 at 197. It has been argued, however, that only dicta supports the "subjective theory." Ibid.

${ }_{75}$ Morris, The Proper Law of a Tort, 64 HARv. L. Rev. 881, 882 (1951). Although the author is principally concerned with the application of "proper law" to torts, he begins with a brief discussion of its application to contracts.

76 Ibid.; Morris, supra note 70 at 206.

77 See notes 81,82 infra, and accompanying text. It could be argued that the doctrine goes too far. Professor Ehrenzweig points out that the great bulk of the "proper law" cases validated the contract, perhaps vindicating his view that validation itself should be a recognized choice of law rnle. See, Treatrse $\$ 1$ 174 at 464 n.33, 465-90 (1962).

78 See, e.g., Goodrich, Conflict of Laws 326-27 (3d ed. 1949).

79 Cheatham \& Reese, Choice of the Applicable Law, 52 CoLum. L. REv. 959, 980 (1952).

80 Ibid.; R. Traynor, Is This Conflict Really Necessary?, 37 Texas L. Rev. 657, 667 (1959).

81 TrEatise $\$ 123$ at 351 .

82 Ibid.

83 Restatenient (Second), Confutct of Laws §332a (Tent. Draft No. 6, 1960). 
to certain provisos, the state of the parties' choice is deemed to have the "most significant relationship." 84 If the parties have not made an effective choice, and the place of contracting and performance coincide, that place is considered to have the "most significant relationship." if there is no effective choice by the parties, and if the places of contracting and performance are not the same, then "additional factors will be considered in determining the state with which the contract has its most significant relationship." ${ }^{\prime 86}$ The draft black letter did not go further, but in the comment it was stated that the traditional factors are to be considered and that if the law of a state upholds a contract, only a considerable majority of the important contacts will override this factor. ${ }^{87}$ The draft was later modified, ${ }^{88}$ however, to list in black letter some of the relevant considerations: the place of negotiating, contracting, performance; situs of subject matter; domicile. ${ }^{89}$ Attention is also to be given to the place whose local law best effectuates the contract. ${ }^{00}$ When the place of performance coincides with the place of negotiation, the law of that state will "ordimarily" govern. ${ }^{91}$

The "most significant relationship" concept, as expressed in the draft, is subject to much the same criticism as is the "proper law" theory. It involves circular reasoning ${ }^{92}$ and, although it provides a list of factors, it fails to evaluate the criteria by which "significance" is to be determined. When the parties have not made an effective choice and the place of contracting and performance do not coincide, there is nothing to consider but a hist of factors. The failure of the draft to be more explicit may encourage courts to adopt the apparently simple solution of counting contacts, ${ }^{93}$ even though the term "significant" implies a more analytical approach. ${ }^{94}$

It has been suggested that a court, faced with only a hist of factors, will probably attribute the most significant relationship to that state which would be chosen under traditional choice of law rules. ${ }^{95}$ If so, the apphication of the theory would achieve the same result as does the mechamical approach to conflicts problems, without achieving the latter's relative certainty.

That an approach which merely considers a list of factors can produce results not in accord with an approach seeking "significance" can be shown by an analysis

84 Id. at $\S 332 \mathrm{a}(\mathrm{a}),(\mathrm{b}),(\mathrm{c})$.

85 Id. at $\$ 332 \mathrm{~b}(\mathrm{a})$.

86 Id. at $\$ 332 \mathrm{~b}(\mathrm{~b})$.

$87 \mathrm{Id}$. at $\$ 332 \mathrm{~b}$, comment $b$.

88 Modified at the 27th annual meeting of the American Law Institute, Nov. 15, 1960.

89 Restatenaent (Second), Conflict of Laws § $332 \mathrm{~b}$ (1) (a)-(e) (Tent. Draft No. 6, as modified, 1960).

$90 \mathrm{Id}$. at $332 \mathrm{~b}(1)$ (f).

01 Id. at $332 \mathrm{~b}(2)$.

92 TrEatise $\$ 123$ at 351 .

93 The contact counting approach is implicit in the "center of gravity" and "grouping of contacts" theories. See, e.g., Auten v. Auten, 308 N.Y. 155, 124 N.E.2d 99 (1954); Rubin v. Irving Trust Co., 305 N.Y. 288, 113 N.E.2d 424 (1953). While this conclusion is not reached from judicial language, the courts failed to articulate any other reason for their decision as to the "center of gravity"; thus it is a safe assumption that the court counted the contacts. TrEatise $\S \S 123,174$ at 351-52, 463-64; Currie, Confict, Crisis and Confusion in New York, 1963 DURE L.J. 1, 39-40. This approach has been unuch criticized. See id. at 30-40; Ehrenzweig, Contracts in the Conficts of Laws, Part I: Validity, 59 Corux. L. Rev. 973-74 (1959).

94 See Cavers, Re-Restating the Conflict of Laws: The Chapter on Contracts, XXTI Century Comparattve and Confltcts Law 349, 355 (1961).

95 Currie, supra note 93 at 40. 
of a New York case, Haag v. Barnes ${ }^{96}$ In the Haag case, Mr. Barnes, an Illinois attorney, while on a business trip to New York, employed Miss Haag, a New York resident, as his secretary to assist hin when he was in that state on business. Their relationship became non-professional and Miss Haag became pregnant. Barnes' attorney advised her to go to an Illinois hospital, where the child was born. Later the parties executed a child support agreement in Illinois, and agreed that their contract would be governed by the law of that state. In return for his promise to pay 275 dollars a month until the child reached sixteen years of age, Barnes was to be free of all further obligation. Miss Haag agreed not to sue to establish Barnes' paternity. After a two year sojourn in California with the child, Miss Haag returned to New York and there instituted a support proceeding against Barnes. Barnes pleaded the Illinois agreement as a complete defense. Under Illinois law a father could compromise all his legal liability without court approval, so long as the compromise sum agreed upon was in excess of 800 dollars. ${ }^{97}$ New York law provides that any agreement or compromise made by the mother shall be binding only with court approval..$^{98}$ The New York Court of Appeals applied Illinois law and affirmed a dismissal of the coinplaint.

At first glance this result seems acceptable. Since Barnes liad made a rather generous provision for the child, the chances are that had the agreement been made in New York the local court might well liave approved it. However, before concluding that the welfare of the child was fully protected, ${ }^{89}$ the court, following a leading New York case, Auten $v$. Auten, ${ }^{100}$ proceeded to analyze the "significant contacts" in the case. It is this analysis which gives rise to concern.

The court noted that Illinois had been the place of contracting and also that its law had been closen by the parties as the governing law. The court stated, however, that although under the traditional view these factors would be given decisive effect, under a most significant contacts test, they are only to be given heavy weight, and other "important" factors are to be considered. ${ }^{101}$ These were: (1) the agreement stated that both parties were from Illinois, and the defendant's place of busmess was there, (2) the child was born in Illinois, (3) the designated agents were Illinois residents, and (4) the support was contributed from Illinois. ${ }^{102}$ The court found that the New York contact with the case-that the child and mother presently lived there ${ }^{103}$ - was of far less significance and con-

969 N.Y.2d 554, 175 N.E.2d 441, 216 N.Y.S.2d 65 (1961). See Currie, supra note 93 at 39; Ehrenzweig, The "Bastard" in the Conflict of Laws-A National Disgrace, 29 U. CHI. L. REv. 498 (1962).

97 See Hagg v. Barnes, 11 App. Div.2d 430, 433, 207 N.Y.S.2d 624, 628 (1960). It is interesting to note that the Illinois law has since been changed, so that such an agreement would no longer be possible. See Irr. Rev. STat. ch. 17, §§ 1-18 (1959); Irr. REv. Stat. ch. 1063/4, $\S 65$ (1959).

88 See 9 N.Y.2d at 558-59, 175 N.E.2d 441, 216 N.Y.S.2d at 68.

${ }^{89}$ Id. at 561,175 N.E.2d at 444,216 N.Y.S.2d at 70.

100308 N.Y. 155, 124 N.E.2d 99 (1954).

1019 N.Y.2d at 559, 175 N.E.2d 444,216 N.Y.S.2d at 68.

102 Ibid.

103 The case was treated as if at all relevant times Miss Haag was a resident of New York, although dissenting justices thought the record was not clear on this point and urged remand to determine Miss Haag's residence at the time of the contract. 207 N.Y.S.2d at 629-31. Since this was not done, the court apparently thought it unade no difference. See Currie, supra note 93 at 44 . What is significant is that mother and child are now residents of that state. See note 109 infra and accompanying text. 
cluded that the "center of gravity" must be in Illinois, and therefore Mllinois law should apply..$^{104}$

Any analysis which calls for a determination of "significance" must begin with a consideration of the issues in the case. In the Haag case there was a conflict between Illinois law, which appeared to favor protecting fathers of illegitimate children, ${ }^{105}$ and New York law, which appeared to be principally concerned with the welfare of the illegitimate child. In addition, the general policy of upholding the intention and the reasonable expectations of the parties should be considered. The significance of the contacts with the case supposedly is determined in light of these competing social and economic policies. From this point of view, an examination of the considerations listed by the court discloses that most of them are completely irrelevant to the issues involved.

It is clearly unimportant where Barnes' place of business was located; his profession had no connection with the contract. The place of the child's birth was arranged by the defendant. The residences of the designated agents cannot be considered relevant since they were not parties to the contract. The place from which the payments were made does not seem to bear on the issues involved; an arrangement easily could have been made for payment to Miss Haag in person in New York. None of these contacts seem to bear any relation to the policies to be considered. Party autonomy, while favored by most writers, ${ }^{108}$ can be discounted in this case, on the justifiable supposition that the contract was either one of adhesion, ${ }^{107}$ or that it was against public policy, ${ }^{108}$ or both. What the court dismissed as of little significance-the residence of mother and child-is perhaps the most "significant" contact, at least from the point of view of the New York policy as expressed in its law. ${ }^{100} \mathrm{It}$ is likely that what the court did was simply to count contacts. ${ }^{110}$ The court expressly equated the "most significant relationship" with the "center of gravity."111 Moreover, although the court stated that the place of contracting and performance were not conclusive, it nevertheless may have given decisive effect to those traditional contacts. In any event, no real analysis of significance was made.

If the court had applied the "most significant relationship" theory, as set out in the Restatement's draft on contracts, the result would probably have been the

1049 N.Y.2d at 560 , 175 N.E.2d at 444,216 N.Y.S.2d at 69.

105 This policy has since heen abandoned by Illinois. See Irx. REv. STATS., ch. 1063/4, $\$ 65$ (1959). See note 97 sucpra.

106 See, e.g., Treatrse $\$ 176$ at 467-68; Mann, suppra note 70.

107 The facts would indicate that Miss Haag signed the contract on a "take it or leave it" basis. She was instructed to come to Chicago to give birth to the child, and apparently was only allowed to discuss settlement with Barnes' attorneys. Most courts hold that "party choice" in such adhesion type contracts is not controlling. This is recognized as a "cogent" exception to Professor Ehrenzweig's "true rule" of validation. See TREATTSE $\$ 183$ at 485-90.

108 Public policy is generally held by most courts to negate party choice and is another cogent exception to Professor Ehrenzweig's "true rule" of validation. See ibid. The argument is weaker in this area since the settlement was rather generous.

100 Since New York's policy is to protect the child's welfare, it is obviously significant that the child and its mother are now resident, if not domiciled, in that state. See Currie, sulpra note 93 at 44 ; Ehrenzweig, sucpra note 96 at 499.

110 There were simply more contacts in Illinois. When a court lists contacts, most of which are irrelevant to "significance," and then decides that the state with the most listed has the "most significant relationship," without any discussion or analysis, it is most probable that it merely counted the contacts.

1119 N.Y.S.2d at 560, 175 N.E.2d at 444, 216 N.Y.S.2d at 69. See note 93 supra. 
same and for similar reasons. The parties had chosen Illinois law. The draft provides that such a choice is controlling, unless one of three exceptions apply. ${ }^{112}$ In this case either draft section 332a(a) (adhesion) or section 332a(c) (public policy) probably applies, ${ }^{113}$ so the parties' choice would be ineffective. The next step would be the localization of the places of contracting and performance to determine if they coincide. ${ }^{114}$ The former was in Illinois, and it could be argued that the latter was also in Illinois. This would result in the application of Illinois law, but in Haag it is rather difficult to see why Mllinois has the "most sigfinficant relationslip." If the court did not find that Illinois was the place of performance, the draft would require the court to consider its list of factors. ${ }^{115}$ Like the court in Haag, which used its own list of factors, a court applying the draft rules would probably reach its decision by simply counting contacts. Again, no policy analysis would be made. Even if the court in Haag had properly decided that in view of the competing policies involved, the respective residences of the parties provided both New York and Illinois with siguificant contacts, how is the court to decide which is the "most significant"?

Thus, neither the "proper law" theory nor its alter ego, the concept of the "most significant relationslip," is a workable choice of law rule. The same criticism directed at the doctrine's application to contracts is applicable to a choice of law discussion of any area of substantive law.

\section{B. Torts}

With a view to the general dissatisfaction with the traditional choice of law rules in the tort area, Professor Morris has suggested that the "proper law" theory be apphied to torts. ${ }^{116}$ He argues that since English courts have reached sound results by applying the "proper law" doctrine in contract cases, similar results could be obtained by applying the doctrine in tort cases. Morris reasons that since the social policies involved in the various kinds of torts differ fundamentally, socially desirable results cannot be obtained by applying the same choice of law rule to them all. The "proper law" doctrine, he argues, would furnish much needed flexibility. In support of his proposal he points to several kinds of cases, negligence for example, where either the place of the act or harm or both are fortuitous, and application of the law of that place would "offend our common sense." He correctly points out that in conversion cases courts have generally refused to apply the traditional rule, ${ }^{117}$ and that in all kinds of cases mechanical application of the place of harm rule often leads to irrational results. ${ }^{118}$ Morris suggests that intelligent application of the "proper law" theory would eliminate the mechanistic approach; separate consideration of the various

112 Restatedent (Second), Conflict of Laws § 332a (Tent. Draft No. 6, as modified, 1960). The exceptions are: (1) choice obtained by unfair means or mistake, (2) contract has no substantial relationship with the chosen state, and no other reasonable basis for the choice, and (3) application of the choice would be contrary to the pohicy of that state which would be the state of the governing law in the absence of an effective party choice.

113 See notes 107, 108 supra, and accompanying text.

114 Restatement (Second), Conflict of Laws $\$ 332 \mathrm{~b}$ (a) (Tent. Draft No. 6, as modified, 1960).

115 Restatenent (Second), Confitct of Laws \$332b(b) (Tent. Draft No. 6, 1960).

116 Morris, supra note 75 at $883-87$.

117 Id. at 886. See, e.g., Goetschius v. Brightman, 245 N.Y. 186, 156 N.E. 660 (1927).

118 Morris, supra note 75 at $887-88$. 
classes of torts would allow a more adequate analysis of the social policies involved. 110 This would enable a more sophisticated inquiry into the problems of causation and foreseeability, coupled with a balancing of the interests of the states whose laws are involved. Morris goes no further than noting that application of the doctrine will not be easy.

Although his rationale for the "proper law" theory is attractive, Morris fails to articulate the method to be used in applying his proposed analysis. As a result, courts equipped only with a generalized question-begging formula may be forced to count contacts. If so, they probably will emphasize those contacts traditionally considered controlling.

Although Morris points to the success of the "proper law" doctrine in contracts, the success of its alter ego- the "most significant relationship" conceptin contracts is open to serious question. Application of the theory to torts would be even worse. In the contracts field, expressed or implied intention of the parties provides a reference point. While the shortcomings of this vague reference point are apparent, ${ }^{120}$ there is even less to work with in the tort area, where there is seldom an intention of the parties to be considered. Moreover, even if a court were to make the analysis proposed by Morris, it would most likely find that each of the competing states lad a significant contact. How is the court to choose without reference to a necessarily arbitrary standard of "significance"? If the court proceeds simply to count contacts, equal division between the states in question would often be the result. In such a case, courts would no doubt tend to view the state having the traditionally decisive contact as laving the "most significant relationship."121

Prior to the second Restatement's adoption of the "inost significant relationship" theory in its draft on torts, no court had made "proper law" or the "most significant relationship" concept the basis of its decision in a tort case. ${ }^{122}$ This adoption, however, was foreshadowed by an article by the Reporter, Professor Reese. ${ }^{123}$ In the article Reese indicated a preference for maintaining the traditional tort choice of law rules, at least when the place of conduct and injury coincide. He did say, lowever, that "in a rare case where conduct and injury occur in different states, it may be that a more flexible approach should be employed and the case decided by the law of whichever of these two states has the most significant relationship with the parties and the occurrence."124 The draft, in contrast to the more hesitant approach of the article, says that the "most significant relationship" rule is the rule. "The local law of the state which has the most significant relationship with the occurrence and with the parties determines their rights and liabilities in tort." ${ }^{\text {"25 }}$ The draft lists the most "im-

119 Id. at 890 .

120 See Treatrse $\$ 174$ at 462 ; but see Mann, supra note 70.

121 Application of the theory to tort cases is also likely to produce a similar result. See text following note 145 , infra.

122 Since then, courts have purported to follow the draft in the following cases: Lowe's No. Wilkesboro Hardware v. Fidelity Mut. Life Ins. Co., 319 F.2d 469 (4th Cir. 1963);

Babcock v. Jackson, 12 N.Y.2d 473, 191 N.E.2d 279 (1963).

${ }^{123}$ Reese, The Ever Changing Rules of Choice of Law, NETHERTANDS INT'L L. REv, 389 (1962).

124 Id. at 393.

125 Restatement (Second), Conflict of Laws \$ 379(1) (Tent. Draft No. 8, 1963). 
portant contacts that the forum will consider in determining the state of most significant relationship: (a) the place where the injury occurred, (b) the place where the conduct occurred, (c) the domicile, nationality, place of incorporation and place of business of the parties, and (d) the place where the relationship, if any, between the parties is centered."128 The draft also states that "in determining the relative inportance of the contacts, the forum will consider the issues, the character of the tort and the relevant purposes of the tort rules involved."127 The draft explains the application of its "general principle" to eleven particular torts. These specific exanples are enlighteming because they denionstrate Reese's continued regard for the place of harm. In the three situations in which the place of harm is most difficult to ascertain-nultistate defamation, inultistate invasion of privacy and multistate injurious falsehood-the draft determines that domicile or principal place of business of the plaintiff is the most important contact. $^{128}$ In the two areas where admonition is more important than conipensation-interference with the marriage relationship and alienation of parent's affection-the draft says that the place of conduct is the most important contact. ${ }^{129}$ But in the remaining situations, where the compensatory elenient of liability predoininates and where one place of harm can be determined, the draft calls the place of injury the most important contact:130

When the injury occurs in a single, clearly ascertained state and where the conduct which caused the injury also occurred there, the local law of this state will almost invariably govern. When the defendant's conduct and the resulting injury occur in different states, the local law of the state where the injury occurred will usually govern. ${ }^{131}$

Thus, the draft provides an autoniatic answer in one situation-when the conduct and injury both occur in the same state. ${ }^{132}$ In the words of the draft, this rule "leads to certainty of result."133 When the conduct and injury occur in different states, the draft's treatment of the problen is likely to cause courts to resort to merely counting contacts. The draft gives an inadequate analysis of "significance"; although the draft nuay reach a different result when one more contact is added, no explanation for this change is offered, other than the addi-

$126 I d$. at $\$ 379(2)$.

127 Id. at $\$ 379(3)$.

$128 \mathrm{Id}$. at $\$ \$ 379 \mathrm{e}, 379 \mathrm{f}, 379 \mathrm{~h}$.

$120 \mathrm{Id}$. at $\$ \$ 379 \mathrm{i}, 379 \mathrm{j}$.

130 Id. at $\$ \$ 379 \mathrm{a}, 379 \mathrm{~b}, 379 \mathrm{c}, 379 \mathrm{~d}, 379 \mathrm{f}, 379 \mathrm{~g}, 379 \mathrm{k}$.

131 Id. at $\$ 379$, comment $b$.

132 In a rare case exceptions may be made to the rule. Ibid.

133 Id. at \$379a, comment $e$. It also explains Reese's dissatisfaction with Kilberg v. Northeast Airlines, 9 N.Y.2d 34, 172 N.E.2d 526 (1961). Reese discusses the Kilberg case in his article and finds that it is not consistent with the "proper law" theory. Reese, sibpra note 123 at 393-97. In the case the plaintiff's decedent was a resident of New York and had purchased a plane ticket in New York for a flight originating there. The plane crashed in Massachusetts, where the defendant airline was incorporated. Reese assumes that the conduct as well as the injury occurred in Massachusetts (though the former does not appear from the case and is not necessarily true) and therefore finds Massachusetts to have the "most significant relationship" with the case.

The Kilberg court is the same court which originated the "center of gravity" theory, the forerunner of the "most significant relationship" theory. See Treatise $\$ 174$ at 463-64. It is interesting to note that such a sophisticated court refused to adopt an automatic reference to the place of injury-a reference virtually unchanged by the draft. 
tion itself. The following illustrations in the draft's section on personal injuries are representative of its entire handling of the problem:

7. [In state $X, A$ shoots at a bird and hits $B$ in state $X$.] $B$ is domiciled in $X$ and neither resides nor does business in $Y, B$ entered $Y$ for purposes of his own and has no connection with $A$. In the absence of further facts, $Y$ local law will be applied to determine the rights and liabilities of the parties.

8. Same facts as in Illustration [7] except that $A$ and $B$ are both domiciled in $X$ and were members of the same hunting party. In accordance with a plan made in $X$, $B$ was to hunt along a certain line which crossed the $Y$ border for a short distance. $B$ was shot at this point. $X$ has the most significant relationship with the parties and with the occurrence and $X$ local law will be applied to determine their rights and liabilities. ${ }^{134}$

Apparently the added facts- $A$ is domiciled in $X$, the hunting party contained both $A$ and $B$ and the hunting plan was made in $X$-dictate the change in result. The facts concerning the hunt are obviously intended to be an example of the draft's factor (d) - the place where the parties' relationship was centered. In some respects it inay be important that $A$ and $B$ were members of the same hunting party and that plans were made beforehand, but as far as a choice of law is concerned it seems irrelevant that these things occurred in $X$. It appears that these additional "factors" simply add up to enough " $X$ factors" to cause the law of $X$ to be applied. No other explanation is offered by the draft.

Since the adoption of the draft, the "most significant relationship" theory has been invoked by the New York Court of Appeals in Babcock v. Jackson. ${ }^{135}$ $B a b c o c k$ involved a guest suing a driver for injuries resulting from an automobile accident allegedly caused by the driver's negligence. Both host and guest were residents of New York, but the accident occurred in Ontario. The Ontario guest statute precluded recovery and the host obtained a dismissal of the complaint on the ground that Ontario law applied, since the accident occurred there. The court of appeals enumerated the New York contacts-place of residence of host and guest; place where the car was garaged, licensed, and insured; place where the trip began and was to end-and the Ontario contact- "the purely adventitious circumstance that the accident occurred there." 136 The court determined that the policy underlying the Ontario statute was to prevent fraudulent and collusive claims against Ontario insurance companies. ${ }^{137}$ It decided that New York's policy is to compel the host who has negligently injured his guest to compensate the guest. ${ }^{138}$ The court stated that Ontario had no valid "legislative concern" in protecting New York insurance carriers and that New York had the "strongest interest" in the resolution of the case. ${ }^{180}$ Basing their decision on this reasoning, the court of appeals reversed the judgment of dismissal.

$B a b c o c k$ was a relatively easy case and, due to the single contact with Ontario, can be said to fall under the draft's exception to the "almost invariable application" of the law of the place of conduct and injury in personal injury

134 Restatement (SeCoND), Confutct of Laws §379a, comment $f$ (Tent. Draft No. 8, 1963).

18512 N.Y.2d 473, 191 N.E.2d 279 (1963).

136 Id. at 483,191 N.E.2d at 284 .

137 Ibid.

138 Ibid.

139 Id. at 483-84, 191 N.E.2d at 284-85. This language should not be confused with Currie's "governmental interests" theory, since Currie does not speak in terms of relative strengths of interests. See note 150 infra and accompanying text. 
cases. ${ }^{140}$ It is questionable whether $B a b c o c k$ would be helpful to the court should a case arise in which an Ontario host and a New York guest were involved. Assuming that the conduct aud injury occurred in Ontario, the court would not be able to discount completely Ontario's "legislative concern," and contacts would be more evenly distributed. In such a case, a real discussion and analysis of "significance" would be called for, and Babcock would seem of little aid. Recourse to the draft's rule that the law of the place of conduct and injury should apply would avoid the discussion of siguificance and also would be inconsistent with the court's statement in Babcock that "the rights and liabilities of the parties which stem from their guest-host relationship should remain constant and not vary and shift as the automobile proceeds from place to place."141 Although the draft suggests consideration of the purpose underlying the "tort rule involved, ${ }^{2142}$ it offers no assistance to a court faced with two competing rules with diametrically opposed policies. A later case has actually arisen in New York concerning an Ontario guest, an Ontario host and a New York accidentWhite v. Motor Vehicle Accident Indem. Corp..$^{143}$ White was decided under the New York Motor Vehicle Accident Indemnification Law, but discussed Babcock. "If we apply the ratio decidendi of the Babcock case to the facts of this case it is clear that Ontario has the "strongest interest" in the matter. Unless the rule in Babcock is somehow limited to a view controlled by the result in each particular case, it is also clear that New York will [apply Ontario law]."144 White demonstrates that the courts of New York may find difficulty when they try to ascertain the meaming of Babcock. Babcock does not dispel the fear that the courts, purporting to apply the draft's rule but failing to analyze the case, will reach incongruous results. ${ }^{145}$

The rule set out in the draft on torts, though it represents an attempt to get away from the rigid "vested rights" theory, is unworkable as a choice of law rule in tort cases. When the rule does not refer absolutely to the law of the place of liarm, it offers little alternative for the court other than to count contacts, an approach which, in the majority of cases, is likely to end iu the application of the same law that would have been applied under the first Restatement rule.

In order to achieve rational results in conflicts cases other inethods of analysis and other choice of law rules are needed.

\section{III}

ALTERNATIVES

\section{A. The "Governmental Interest" Theory}

In a series of articles Professor Currie has set forth a new approach to the problems of choice of law..$^{146}$ Even before Currie developed his theory, it was a

140 See note 132 supra and accompanying text.

14112 N.Y.2d at 484,191 N.E.2d at 285.

142 See note 127 supra and accompanying text.

143241 N.Y.S.2d 566 (1963).

144 Id. at 574.

145 See, e.g., Lowe's No. Wilkesboro Hardware v. Fidelity Mut. Life Ins. Co., 319 F.2d 469 (4th Cir. 1963).

140 Currie, Survival of Actions: Adjudication versus Automation In the Conflict of Laws, 10 Stan. L. Rev. 205 (1958); Currie, Married Women's Contracts: A Study. in Conflict-Of- 
widely accepted principle that choice of law rules should advance the policies and interests of the several states, ${ }^{147}$ but no workable frame of reference had been advanced to accomplish this purpose. Currie proposes to provide this frame of reference through his "governmental interest" analysis.

Currie's analysis stresses the primacy of forum law. The court first determines the policy expressed in the law of the forum. Next the court inquires whether the relation of the forum to the case provides a "legitimate" basis for the application of that policy. If such a basis is found, the court should in all cases apply forum law, even if another state also has an interest in the application of its law. Currie thus removes from the judiciary the burden of choosing between competing state policies. ${ }^{148}$ Forum law would apply, a fortiori, if the foreign state has no interest; it would also apply if neither state has an interest, because this is the "most convenient mode of disposition."140 If, however, the court finds that the forum state has no interest in the application of its policy, but that the foreign state does, foreign law should be applied. If the forum has no interest but two or inore foreign states have interests, Currie would have the forum apply its own law, since he maintains that the judiciary is unequipped to choose between the competing interests, and moreover, that such a cloice is properly a function of the legislature rather than the judiciary. ${ }^{100}$

The "governmental interest" theory is desirable as a retreat from the traditional choice of law rules. Rather than emphasizing a particular contact or contacts deemed decisive, Currie's theory focuses on the policies expressed by the conflicting laws and the interests of the respective states in applying those policies. In this policy analysis the residences of the parties seem of special significance. ${ }^{151} \mathrm{~A}$ state can generally lave no interest in applying its policy if neither party is a resident of that state. ${ }^{162}$ On the other hand, it appears that the traditional contacts are considered irrelevant, except when they are necessarily involved in the policy. Thus, in a trespass case involving recordation of land titles, situs of the property would be relevant to the policy issue. ${ }^{163}$

Laws Method, 25 U. Cㅍ. L. Rev. 227 (1958); Currie, Notes on Methods and Objectives in the Confiict of Laws, 1959 Duke L.J. 171; Currie, The Constitution and the Choice of Law: Governmental Interests and the Judicial Function, 26 U. CHr. L. REv. 9 (1958); Currie, The Constitution and the "Transitory" Cautse of Action, 73 Harv. L. Rev. 36, 268 (1959); Currie \& Schreter, Constitutional Discrimination in the Conflict of Laws: Equal Protection, $28 \mathrm{U}$. CmI. L. REv. 1 (1960); Currie \& Schreter, Unconstitutional Discrimination in the Conflict of Laws: Privileges and Immunities, 69 YALE L.J. 1323 (1960). It should be noted that this theory is not restricted to contracts; Currie, The Verdict of the Quiescent Years: Mr. Hill and The Confict of Laws, 28 U. Cㅍ. L. REv. 258 (1961); Currie, Justice Traynor and the Conflict of Laws, 13 Stan. L. Rev. 719 (1961); Currie, Conflict, Crisis and Confusion in New York, 1963 DUKE L.J. 1.

${ }_{147}$ See Hill, Governmental Interest and the Conflict of Laws-A Reply to Professor Currie, 27 U. Cㅍ. L. REv. 463, 481 (1960).

148 Currie, Notes on Methods and Objectives in the Conflicts of Laws, 1959 Duxe L.J. 171,176 .

149 Id. at 179.

150 Currie, supra note 148 at 179, 181. Congress may not be in a better position to make the choice. See Ehrenzweig, Choice of Law: Current Doctrine and "True Rules," 49 CarTr. L. REv. 240, 247 (1961).

151 See Currie, Married Women's Contracts: A Study in Conflict-Of-Laws Method, 25 U. CHI. L. REv. 227 (1958).

152 Professor Currie appears to use the terms domicile and residence intercbangeably. A state could presumably have an interest in the case of a non-resident domiciliary. When the residence of the parties is common, this appears to be controlling. See Currie, supra note 151. 153 Currie, supra note 151 . 
Perhaps the chief virtue of the "governmental interest" theory is the elimination of false problems. ${ }^{154}$ This results from Currie's premise that when one of two competing states has no interest in the application of the policy underlying its law, there is no real conflict at all. The application of the theory would in many cases avoid an irrational application of foreign law based on fortuitous contacts of the foreign state with the case, by finding that the foreign state had no interest in applying its policy. ${ }^{155}$ Improper applications of forum law, purportedly based on some notion of local public policy but lacking an examination or articulation of that policy, ${ }_{1}^{156}$ would also be avoided.

Since use of the theory is obviously not meant to be mechanical, the "governmental interest" theory is subject to criticism from those who demand simple and predictable rules; ${ }^{157}$ the lack of justification for such criticism has been indicated above. ${ }^{108}$

At least one eminent writer fears that the inherent difficulty in applying the theory will make it a "dangerous tool in the hands of unskilled courts."159 Assuming there is a danger, still Currie's theory is less dangerous than the "most significant relationship" test. At least in Currie's view, his theory does not require weighing of interests, ${ }^{160}$ while the "most significant relationship" theory does. ${ }^{161}$ This obviates the necessity for the court to make a very difficult choice between the laws of two states, each of which has a "significant relationship" with the case.

Currie, however, would allow the forum to apply its own law only if its interest in so doing is "legitimate." His theory calls for the forum to determine the legitimacy of its interest with "moderation and restraint," 162 giving due regard to the interests of a sister state. ${ }^{163}$ It may be that a moderate and restrained determination of legitimacy is, in fact, the weighing process that Currie

154 Currie, supra note 148 at 178; M. Traynor, Conflict of Lazes: Professor Currie's Restrained and Enlightened Forum, 49 CAIIF. L. REv. 845, 847-51 (1961); R. Traynor, Is This Conflict Really Necessary?, 37 TEXas L. REv. 657 (1959).

165 Currie, supra note 148. See, e.g., Jeffrey v. Whitworth College, 128 F. Supp. 219 (E.D. Wash. 1955).

166 See, e.g., Rubin v. Irving Trust Co., 305 N.Y. 288, 113 N.E.2d 424 (1953); Fox v. Postal Tel. Cable Co., 138 Wis. 648, 120 N.W. 399 (1909) ; Emery v. Burbank, 163 Mass. 326, 39 N.E. 1026 (1895).

107 See, e.g., Hill, supra note 147. Reese, supra note 123, fails to mention Currie's theory. 168 See generally Part $I$ of this comment.

169 See Ehrenzweig, supra note 150 at 241.

160 Currie, supra note 148 at 178 . This is so even though the court must make an evaluation of the interest to see whether it is "legitimate." See text accompanying note 162 infra. Some writers have found difficulty with the "governmental interests" theory because of Currie's refusal to apply foreign law whenever the forum can claim at least a competing interest. See, e.g., Treatise at $350 ;$ M. Traynor, supra note 154 at 852.

161 See Currie, supra note 93 at 40 . Currie uses the term "mystical" to describe the court's pronouncement that a specific state has the "most significant relationship." Since the court is not required to describe how and why their conclusion was reached, the reasoning indeed is a mystery.

162 See. e.g., Currie, Justice Traynor and the Confict of Laws, 13 StAN. L. Rev. 719 (1961) ; Currie, supra note 93. See also, Bernkrant v. Fowler, 55 Cal. 2d 588, 360 P.2d 906, 12 Cal. Rptr. 266 (1961). In Bernkrant, a case using interest analysis, Justice Traynor noted that the forum state, Cahifornia, could be held to have an interest in the apphication of its law, but proceeded to define that interest with restraint and moderation and applied the foreign law. See Currie, Justice Traynor and the Conflict of Laws, 13 StaN. L. Rev. 719, 778 n.236.

103 Currie, supra note 93 at 1. 
wants the judiciary to abdicate. ${ }^{164}$ To the extent that this is true, Currie's theory becomes more difficult to apply, but at the same time much of the criticism of Currie's failure to weigh becomes unwarranted. ${ }^{105}$

Since the moderate and restrained determination of legitimacy applies only to the forum state's interest, ${ }^{166}$ the "governmental interests" theory breaks down when the forum is disinterested and there are two or more competing foreign states. In such a situation, Currie would have the court, which in his view is unable to choose between the foreign laws, simply apply forum law. Thus, when the forum is disinterested, application of the "governmental interest" theory is not only unworkable, but it may defeat the very purpose for which the theory was formulated. ${ }^{167}$ It has been suggested, however, that a choice by the forum between the competing interests of the foreign states is possible within the framework of Currie's theory. ${ }^{168}$

Currie's "governmental interest" theory obviously does not solve all choice of law problems. It does not purport to. It is submitted, however, that Currie's theory, while not perfect, would be a more workable alternative to the rule of the first Restatement, than is the "most significant relationship" concept.

\section{B. "The Foreseeable and Insurable Laws" Theory}

Another possible alternative to the first Restatement's place of harm rule in cases of enterprise liability is the "foreseeable and insurable laws" theory proposed by Professor Ehrenzweig. ${ }^{168}$ Ehrenzweig's approach to the problem, which ultimately results in the formulation of his theory, can be briefly summarized. He takes the view that the basic rule in the conflicts law of torts refers to the lex fori. ${ }^{170}$ From this starting point he looks in each situation to the development of a common law of conflicts, based on "consistent judicial practice," to provide exceptions to the basic rule. ${ }^{171}$ He envisages that this approach will actually promote application of foreign law and relegate the lex fori, as a basic

164 TREATISE $\S 122$ at $350-51$; M. Traynor, supre note 154 at 852 .

105 TREATISE $\S 122$ at 351 .

106 See Currie, supra note 93 at 1 .

167 In such a case, obviously the legitimate interetsts of two states are being defeated, while at the same time the forum is not advancing a legitimate interest.

108 See Schreter, "Quasi-Community Property" in the Conflict of Laws, 50 CaLr. L. Rev. 206 (1962); M. Traynor, supra note 154 at 855.

169 See Ehrenzweig, Guest Statutes in the Conflict of Laws-Towards a Theory of Enterprise Liability under "Foreseeable and Insurable Laws," 69 YaLE L.J. 595 (1960) ; Ehrenzweig, Products Liability in the Conflict of Laws-Toward a Theory of Enterprise Liability under "Foreseeable and Insurable Laws," 69 YALE L.J. 794 (1960); Ehrenzweig, Vicarions Liability. in the Conflict of Lazes-Toward a Theory of Enterprise Liability under "Foreseeable and Insurable Laws," 69 YALE L.J. 978 (1960).

Ehrenzweig has rephrased the rule to refer to "foreseeable and calculable laws," rather than to "foreseeable and insurable laws." TREATISE § 226. "Calculability" would appear to he a meaningful eleinent in the formulation of a choice of law rule only so far as it relates to "insurability." Ehrenzweig, in fact, seems to use the word "calculable" as a symonym for "insurable." See TREATISE $\S 217$ at $570, \S 219$ at $575-77, \S 220$ at $580-81, \S 223$ at 590-92. Therefore, the term "insurable" will be used throughout this discussion in place of the tern "calculable."

170 See generally Ehrenzweig, The Lex Fori-Basic Rule in the Conflict of Laws, 58 Mrcr.

L. REV. 637 (1960).

171 See TREaTISE \& 122 at 350. 
rule, to mere analytical primacy, ${ }_{172}$ because deviations from the lex for $i$ should not occur, in his view, except when "compelling reasons" for such deviations exist. ${ }^{173}$ In cases of enterprise liability, Ehrenzweig believes that "compelling reasons" exist when the lex for i is not a "foreseeable and insurable" law. ${ }^{174}$ Under this view, the plaintiff can choose among any of the "foreseeable and insurable laws" merely by his choice of forum, assuming that he can meet jurisdictional requirements. ${ }^{175}$ Ehrenzweig appears to think it not improper that the plaintiff be allowed the benefit of the most favorable foreseeable law by simply suing in the "foreseeable" forum most convenient to him and thus obtaining the application of the law of his choice. ${ }^{176}$

Critical analysis of the Ehrenzweig theory unust begin with an examination of the reasoning underlying it. Ehrenzweig, after recognizing the lex fori as the basic rule, discards the Restaters' place of harm rule as not properly serving the primary purpose of enterprise hability, the compensation of the plaintiff. $177 \mathrm{He}$ then states that aniong the "primary interests [which must be considered by a choice of law rule] are the interests of the [defendant] in procuring liability insurance adequate under the applicable law, and the interests of his insurer in the reasonable calculability of premiums." ests are not properly served by reference to either the law of the fortuitous place of accident, the law of a possibly equally fortuitous forum, or by a usually inconclusive reference to the law 'preferable' on grounds of policy."179 The plaintiff, in Ehrenzweig's view, must not be allowed the benefit of any laws whose application the defendant could not foresee, because only foreseeable laws can be insured against. ${ }^{180}$ The plaintiff can choose as he wishes from among the foreseeable laws since the defendant could have insured himself against the application of each of those laws, whether or not he actually did so. ${ }^{181}$

The reasoning underlying the Ehrenzweig theory appears to involve at least three basic premises. First is the proposition that the primary purpose of enterprise bability is the compensation of the plaintiff. This proposition has been discussed above, ${ }^{182}$ and its vahdity seems unquestionable. The second premise is that two of the prime interests which must be served by a choice of law rule

172 Ibid. Ehrenzweig actually foresees the further broadening of jurisdictional concepts so that all applicable laws will be available to the plaintiff. On the other hand, he foresees a narrowing of those concepts which prevent suit in any other forum. See TrEaTISE $\S 124$ at 352. In the meantime, choice of law rules are necessary and only the part of Ehrenzweig's theory which deals with such rules will be discussed.

173 TREATISE $\S 213$ at 555 .

174 See authorities cited note 169 , supra.

175 TREATISE $\$ 224$ at 592-93.

${ }^{176}$ See Ehrenzweig, Products Liability in the Conflict of Lawe-Toward a Theory of Enterprise Liability under "Foreseeable and Insurable Lazes," 69 YALE L.J. 794, 800-01 (1960). The suggestion that the plaintiff be allowed his choice of the applicable laws was made by Cook as early as 1942. See COOK, THE LOGICAL AND Legax Bases OF the Conflict OF Laws 345 (1942).

177 See Ehrenzweig, Guest Statutes in the Confict of Laws-Towards a Theory of Enterprise Liability under "Foreseeable and Insurable Laws," 69 YaJE L.J. 595, 598 (1960).

178 Id. at 603.

170 Ibid.

180 Ehrenzweig, supra note 176 at 801.

181 See $i d$. at $802-03$.

182 See note 35 supra and accompanying text. 
are the defendant's interest in insuring himself against the claim, and his insurer's interest in calculating the premium. Insurance, whether "self-insurance" or not, distributes the burden of enterprise hability. ${ }^{183}$ Consequently, it is not difficult to agree with the second premise. The key assumption underlying Ehrenzweig's theory is the third premise - that a choice of law rule must refer only to "foreseeable" laws because only the application of "foreseeable" laws may be insured against. Necessarily included therein is the secondary premise that insurance premiums will be $\mathrm{e}^{184}$ determined by reference to "foreseeable" laws.

In order to facilitate an understanding of the theory and to provide a framework within which the vahdity of Ehrenzweig's major premise may be discussed, his explanation of the theory's application in three specific areas of enterprise liability will be considered: motorists' liability to their guests, products liability and vicarious liability. ${ }^{185}$

Ehrenzweig finds the place of harm rule inadequate in the area of motorists' liability to their guests. ${ }^{186}$ Apphication of the place of harm rule could cause the defendant to be held liable under a standard of ordinary care when both he and the plaintiff reside in a state which lias a guest statute which creates liability only in instances of gross negligence. The place of harm in such a case is fortuitous, thus its law is unforeseeable. Assuming the plaintiff sues the defendant in the state of their common residence, application of the "basic rule" of the lex fori would solve this difficulty. But the defendant may be caught in a "transient" forum, so that the lex fori will be as fortuitous and unforeseeable as the law of the place of harm. Accordingly, Ehrenzweig declares that the only foreseeable and thus insurable law is the law of the state where the insured car is permanently garaged. Because the car is generally garaged in the state of the defendant's domicile, the application of the law of the common domicile also is acceptable. Ehrenzweig contends that the law of the place where the car is garaged can be considered by both the host and the guest in arranging their insurance programs. Whether the "law of the garage" imposes hability only for gross negligence or for simple negligence as well, the host could adjust his coverage accordingly. His insurer could calculate the premium on the same basis. The guest would be aware of the extent of his protection and could intelligently decide whether or not to purchase his own accident insurance. Elrenzweig believes that the existing case law is generally consistent with the "law of the garage" rule in cases involving motorists' liability to their guests. ${ }^{187}$

Products hability cases present a different problem. Ehrenzweig views this

183 See C. R. Morris, Enterprise Liability and the Actuarial Process-The Insignificance of Foresight, 70 YaLE L.J. 554, 555 (1961).

184 Ehrenzweig appears to phrase this subsidiary premise in terms of "could" be determined, and admits that, in fact, they are not so determined. See TrEatise $\$ 220$ at 580-81. This admission removes any possible rational grounds for the application of "foreseeable" laws. See notes 203-05 infra and accompanyping text. The admission is forced by a defect in the rule. See notes 192-202 infra and accompanying text. So that this defect can be fully explained, this comment phrases the subsidiary premise, in conformity with the logic of the theory, in terms of "will" be determined, rather than "could" be determined.

185 See articles by Professor Ehrenzweig cited in first paragraplı of note 169 supra.

186 Ehrenzweig, supra note 177 at 602-04. It may be argued that such liability is not properly classified as enterprise liability. Professor C. R. Morris, lowever, approves of the classification. See C. R. Morris, supra note 183 at 555.

187 See the recent case of Babcock v. Jackson, 12 N.Y.2d 473, 191 N.E.2d 279 (1963). See text accompanying note 136 supra. 
area of conflicts law as "one of novel impression in most jurisdictions." It consequently "Iends itself most readily to the formulation of a rational solution, unburdened by concepts and rules drawn from the dogmatic interlude ... which produced [the Restatement]." $188 \mathrm{He}$, therefore, feels free to discuss the application of the "foreseeable and insurable laws" rule in this area without the necessity of rationalizing existing case law. Due to the "basic rule" of the lex fori and to the modern development of the law of jurisdiction, the plaintiff is able, in most cases, to choose the law most favorable to him by choosing the forum in which to bring suit. This is consistent with the principle underlying products liability-coinpensation of the plaintiff. The defendant is able to foresee the laws of those states in which his product may be distributed and can take into account the most unfavorable in determining his pricing and insurance policies. Situations may arise, however, in which the plaintiff is unable to obtain jurisdiction in a state whose law was foreseeable or the plaintiff may obtain jurisdiction over the defendant in a state whose law was not foreseeable. In these instances, the lex fori will not provide an acceptable result. Therefore, Ehrenzweig would allow the defendant to object to the application of any non-foreseeable law, and the plaintiff to "claim applicability of any 'proper' law-usually that of the defendant's place of business or the plaimtiff's residence."189 Ehrenzweig recognizes that this may result in the plaintiff recovering from an out-of-state defendant although he could not have recovered from a domestic defendant. This result is acceptable, despite the unwarranted boon to the plaintiff, since products liability must be based primarily on the defendant's foresight and cannot meaningfully take into account the plaintiff's calculations, as in motorist-guest situations. It seems that Elrenzweig would favor a rule allowing the plaintiff to rely on any "proper" law regardless of the forum, rather than allowing him to so rely only in a forum whose own law is inapplicable. Apparently Ehrenzweig's "foreseeable law" in this area is the law of any state in which the defendant can foresee distribution of his products, but it is unclear whether the "proper" laws from which the plaintiff is allowed to choose are coterminous with the foreseeable laws or include only certain among them.

As an example of vicarious hability, Ehrenzweig takes the case of the liability of an automobile owner-renter for accidents caused by the neghigence of the driver. ${ }^{100}$ If cars are owned and rented in a state which by statute has made the owner liable, the law of that state is a foreseeable and thus insurable law and should be applicable whether or not the accident happened to occur in a state without such statutory liability. The defendant is not allowed to avail himself of the more lenient law. If the defendant owns and rents cars in a state which has not created liability by statute, Ehrenzweig believes that, while the defendant primarily may consider his own law, he inust foresee that cases will arise in which "the impact of stricter foreign laws is clearly unavoidable."191 This will occur when the defendant consents to a car being taken to a state which has an

188 Ehrenzweig, supra note 176 at 794-95. He discusses this area of enterprise liability id. at $800-03$.

189 Id. at 803.

190 Ehrenzweig, Vicarious Liability in the Conflict of Laws-Toward a Theory of Enterprise Liability under "Foreseeable and Insurable Laws," 69 YALE L.J. 978 (1960). He discusses this area of enterprise hability id. at 986-88.

101 Id. at 986. 
owner's liability law and the accident occurs there. Since the application of the stricter law is foreseeable, the defendant could have insured against it. But the plaintiff, a resident of the foreign state, cannot be expected to have insured against the application of the defendant's law. Accordingly, the defendant must be held under the stricter "foreseeable and insurable" law, regardless of where the suit is brought. Since it is not unusual in the car rental business for a rented automobile to be taken out of state without consent, an accident in another state is foreseeable. Because the owner can insure against this application of foreign laws the same result must be reached as if consent lad been given. In Ehrenzweig's view, the "foreseeable and insurable laws" include the law of the place where the car is permanently garaged, the law of the plaintiff's residence and the law of the place of accident. The plaintiff should be allowed to choose among these laws by forum shopping. The defendant may protest only if the lex fori, in any given case, was unforeseeable and thus uminsurable. Elirenzweig would allow this defense when the states in whicl the car is garaged, the plaintiff resides, and the accident occurred, are all states lacking an owner's liability statute, even though "transient" jurisdiction is obtained over the defendant in a state having an owner's liability law.

Obviously Ehrenzweig intends the "foreseeable and insurable laws" theory to be flexible-what laws will be foreseeable and insurable will differ among the various liabilities classified under the broad category of enterprise liabihity, though the same principle will apply throughout. This is only reasonable; products liability and the vicarious liability of a car owner for accidents caused by a driver seem to differ significantly as regards foreseeability. However, Ehrenzweig's concept of foreseeability, as it relates to insurance, should be compared with the realities of insurance practice.

A private owner of an automobile generally takes out insurance on a yearly basis, not on the basis of individual trips. ${ }^{192}$ Similarly, a gnest ordinarily will not take out his own accident insurance for eacl specific trip he may make in someone else's automobile. Accident insurance normally covers a substantial period and many risks, so that it makes no sense in an insurance context, to speak of foreseeability in terms of specific trips by either lost or gnest. Rather, it must relate to overall exposure to risk, as seen at the time the policy is written. Consequently, Ehrenzweig's comment that "it seems unreasonable to compel the lost ... to buy insurance against a liability that lie might incur under the law of a state possibly to be reached on a yet unplanned out-of-state trip,"193 is not always justifiable. There may be car owners who can foresee that they will take out-of-state trips in the coming year and who can, therefore, insure against the application of the laws of the states which they believe they may travel througl. In such cases it is not "unfair" to hold the defendant under the law of state $X$ when he has foreseen and could have insured against its application, even thougli the specific trip which resulted in such application was unforeseeable. Of course, there may be owners who cannot foresee that they will leave their domicile at all. Yet even here it is not really correct to say that because only the "law of the garage" is foreseeable and thus insurable, the lost must not be held liable under the law of another state. The actual practice of insurance companies demonstrates the error. 
As a practical matter the insured does not pay for a policy which covers only the risks he foresees for himself. ${ }^{194}$ The insurer will charge a premium which will return a certain profit above anticipated expenses, including anticipated claims. Anticipated claims are computed by an actuary who examines the past experience of a group in which the particular driver is classified. ${ }^{195}$ To the extent that potential claims under foreign laws affect the computation, ${ }^{196}$ they are estimated on the basis of the group, not the individual insured. ${ }^{197}$ Even though a particular driver foresees possible accidents that would result in the application of foreign law, and even though his insurance will cover such accidents, he pays only his share of the cost of insuring the group against such risks. ${ }^{198}$ This is true for the car-renter as well. His own estimate of the number of drivers likely to be involved in accidents resulting in the application of foreign law, and his estimate of the aggregate amount of the recoveries, will not determine what premium he pays. The past experience of a group in which the carrenter is classified will govern the determination of his premium. He will bear his share of the amount attributable to claims recovered under foreign law without regard to what he foresees as his own risk. Though products liability insurance rates are set in a somewhat different manner, ${ }^{199}$ the premium that the entrepreneur pays is also a reflection of his share of a generalized group risk rather than an estimate of his personal risk based on the nost unfavorable law of the states in which he may distribute his product. ${ }^{200}$

It becomes apparent that the application of laws which are "unforeseeable" by the group to which the defendant belongs will have a negligible effect on the defendant's premium. ${ }^{201}$ Consequently, he cannot complain when such "unforeseen" laws are applied to hin in a specific case. It is possible that laws, "unforeseeable" by a particular defendant, may be applied so often to the group that they become "foreseeable" for the group, therefore affecting premiums. Nevertheless, in the group context, "either the risk is 'foreseeable and insurable', or it is de minimis."202

Even though insurance premiums are not calculated with reference to the individual defendant's estimate of his risk, it might be argued that the "foreseeable and insurable laws" theory has vahdity in the area of "self-insurance" programs. The entrepreneur who "insures himself" will take into account only those risks that he foresees and will set aside reserves ${ }^{203}$ sufficient to pay his estimate of potential claims. However, the basic reasoning behind the "foreseeable and insurable laws" theory creates a difficulty even in the "self-insurance" area. "The [rule] would have the law decide which losses should be charged to

104 See C. R. Morris, supra note 183 at 574.

105 Id. at 568 . The classification will depend on age, sex, marital status, and the state and perhaps region of the state in which the car will be primarily used.

190 On the effect of the application of differing laws on insurance rates, see $i d$. at 578 .

197 Id. at 574 .

198 See id. at 577 .

190 See id. at 569-74.

200 Ibid.

$201 \mathrm{Id}$. at 577 .

$202 I d$. at 578.

203 Theoretically the "self insurer" would price so as to cover only his own estimated expense. This does not imply that the entrepreneur will necessarily be able to shift the entire burden of his enterprise liability to his customers through pricing .See id. at 585 . 
the entrepreneur by discovering what losses he has provided for. But the entrepreneur provides for the losses the law dictates he must bear. The [rule], then, is tautological. The rules of liability are to be dictated by insurance practices which are, in turn, dictated by the rules of liability."204 The self-insurer, as well as the insurance company, can only take into account the laws which the conflicts rule in force in the various states make applicable - these and only these are the "foreseeable and insurable laws." 205 It is true enough that, should the courts impose liability based on the specific allocations suggested by Ehrenzweig, such as the "law of the garage" in motorist-guest cases, insurance practice would follow and these laws would become the "foreseeable laws." The trouble is that the laws applicable under any rule followed by the courts, no matter what its rationale, will be reflected in insurance practice and thus become the "foreseeable and insurable laws." If it must be justified by the relation of foreseeability to insurance, the theory's reference to "foreseeability" appears to be unwarranted.

Nevertheless, the "foreseeability" theory deserves furtler consideration. Courts need a workable and reasonable basis for making a choice of law in enterprise liability cases. The theory that will provide sucl a basis should be concerned primarily with the compensation of the plaintiff, the predominant purpose of enterprise liability, and also should treat the defendant fairly. It may be that the "foreseeability" theory meets these requirements once "insurability" is disregarded as a justification. ${ }^{206}$ This can be determined only by examining the concept of "foreseeability" through an inspection of exactly which laws are, in Ehrenzweig's view, the "foreseeable" laws in various situations.

In cases involving a car owner's liability for an accident caused by a driver. of the car, Ehrenzweig says the law of the plaintiff's residence, the law of the state where the car is permanently garaged and the law of the state of accident are foreseeable laws, ${ }^{207}$ whether or not the rental agency had consented to operation of the car outside the state of rental. Here Ehrenzweig looks at foreseeability in terms of the specific accident. He allows the defendant to object to the application of the law of a forum in which the plaintiff lad obtained merely "transient" jurisdiction. ${ }^{208}$ The defendant, viewing his overall risk, may well have foreseen application of that law in some circumstances. Thus he can be allowed to object to its application only because it was unforeseeable in the specific case. But even limited to the specific occurrence, in what sense can it be said that the law of the plaintiff's residence or of the place of accident (in cases where consent was not obtained) is foreseeable? It seems clear that the rental agency, even at the moment of renting the car, is totally unable to foresee the state of residence of a person yet to be imjured. As to the place of accident, the law of any contiguous state is foreseeable if there is a reasonable possibility that the driver will have an accident in that state. But if this is so, and if one of those contiguous states should liappen to be the "transient" forum in which the defend-

204 Id. at 581-82.

205 See id. at 581-83. Ehrenzweig appears to recognize the validity of this statement when he says "once the courts have imposed liabilities based on such an allocation, however arbitrary, insurance practice will follow." Ehrenzweig, supra note 176 at 801-02.

200 Ehrenzweig himself has dropped the "insurability" terminology from his statement of the rule, but still appears to rely on it to justify the rule. See discussion at note 169 supra. 207 Ehrenzweig, supra note 190 at 988.

208 Ibid. 
ant is caught, what justification would he have for his claim that its law was unforeseeable? It appears that the laws applicable under Ehrenzweig's theory are not really the "foreseeable laws"; instead they are the laws of states having some "relevant contact" with the case. 200

The same conclusion can be reached by an examination of Ehrenzweig's treatment of products liability. The plaintiff, if unable to bring suit in any state having a "contact" with the case (here Ehrenzweig focuses on the defendant's domicile and the place of wrong, which he beheves will be characterized as the plaintiff's residence), must be allowed to choose among all "proper" laws. ${ }^{210}$ Here also the defendant's domicile and the plaintiff's residence are singled out as "usually" being the "proper" laws from which the plaintiff can choose.211 But the law of the plaintiff's residence need not have been foreseeable by the defendant. The defendant may distribute his products only in a few New England states and it seems incorrect to say that he can foresee the application of the Iaw of California, plaintiff's residence. It appears, therefore, that the laws which Ehrenzweig wonld hold applicable in products liability cases are no more "foreseeable" than are those in the car owner's liability area. Again they are the laws of states having some "relevant contact" with the case.

The "foreseeable laws" theory, if so interpreted, can be analyzed as having nothing to do with "insurability" or "foreseeability"; it instead establishes an ambit of "proper" laws 212 from which the plaintiff is able to choose, by means of forum shopping, the most favorable law. Should the plaintiff, as a practical matter, be unable to sue or to obtain jurisdiction in the state of his choice, the rule may be considered as allowing him to use any "proper" law. ${ }^{213}$ Such a rule provides for the plaintiff's compensation, since lie is able to choose ${ }^{214}$ among the laws of those states having some "relevant contact" with the case and will usually find a favorable law. Of course, cases may arise in which the plaintiff would be denied recovery, or allowed only a limited recovery, under all the "proper" laws. It might be suggested that in such a case the application of some other law of the plaintiff's choosing would more adequately serve the purpose of compensating the plaintiff. In requesting such an application, however, the plaintiff has no justification, other than his desire for recovery. It is submitted that denial of the plaintiff's right to choose any law is justified on the grounds of fairness to the defendant. Aside from an instinctive feeling that the allowance of such a right to the plaintiff would be unfair to the defendant, there is the defendant's or his insurer's interest in being able to make an intelligent choice regarding settlement. If the plaintiff is restricted to the laws of those few states having "relevant contacts" with the case, the defendant or his insurer will be able to take these laws into account in deciding, even before the case gets to

200 Ehrenzweig has used the language of "relevant contacts" to explain cases in which the lex fori was not applied. Id. at 978.

210 Ehrenzweig, supra note 176 at 802-03.

211 Id. at 803 .

212 The phrase "proper" laws is used here to refer to a certain number of laws, any one of which can properly be apphied to the case. This is the way Ehrenzweig uses the phrase. See Treatuse $\$ 174$ at $464-65$. It is to be distinguished from the "proper" law referred to by the "most significant relationship" theory.

213 As has been mentioned, Ehrenzweig appears to favor such a result.

214 See authorities cited note 176 supra. 
court, whether or not to settle, and at what figure. On the other hand, if plaintiff is able to choose any law it is almost impossible for the defendant to estimate his chances for success in a possible lawsuit. Consequently, it appears that the "foreseeable and insurable laws" theory, interpreted as referring not to "foreseeable" or "insurable" laws, but to the laws of those few statés having some "relevant contact" with the particular case, serves to compensate the plaintiff while insuring a sufficient degree of predictability of result to protect the defendant and his insurer. That this reformulation, while deviating widely from Ehrenzweig's terminology, does not seem radically inconsistent with his intent, is evidenced by the laws he would have apply in specific instances. Ehrenzweig himself las disregarded foreseeability as it relates to insurability, ${ }^{215}$ and occasionally has disregarded even the concept of foreseeability itself.210

It might be argued that a "foreseeable and insurable laws" rule, reformulated so as to refer to the laws of a small class of states laving "relevant contacts," would, in practice, be so vague that a court could reach any result while purporting to apply the rule. To be sure, there appears to be a certain degree of flexibility im the definition of a "relevant contact," as evidenced by the range of laws which Elirenzweig would consider applicable in various situations. The range of applicable laws, however, can be narrowed.

In most, if not all, conflicts cases involving enterprise liability, the plaintiff's residence and the defendant's residence (or principal place of business) should be considered the only states having "relevant contacts" with the case. Ehrenzweig's deviations from this definition can be explained, in large part, by his preoccupation with insurability. Elirenzweig's insistence on the applicability of the law of the state of the garage in motorist-guest cases ${ }^{217}$ and his substitution of that law for the law of the domicile of a car rental agency ${ }^{218}$ are examples of such deviations. The state of the garage does not, as such, appear to have a "relevant contact" with the case. Consequently, the law of the state of the garage should be treated as acceptable only because the state of the garage and the defendant's domicile are usually the sane. This is essentially the reverse of the manner in which Ehrenzweig, emplrasizing insurability, has explained the relative acceptability of the two laws. ${ }^{219}$ Reference to the law of the place of accident ${ }^{220}$ also deviates from the normal reference to the laws of the defendant's and the plaintiff's residences. Since the place of accident is clearly fortuitous, ${ }^{221}$ as Ehrenzweig recognizes, reference to that law camot be justified once rehance on "foreseeability" and "insurability" is discarded. Vagueness does not appear to be a valid objection to the Elrenzweig rule once it has been redefined to refer only to the laws of the plaintiff's and defendant's residences. It is possible that in certain situations exceptions to the "law of the places of residence" may be required. For instance, more than one principal place of business may have to be attributed to corporate defendants

215 Ehrenzweig disregards insurability when he focuses on foreseeability as regards specific accidents, rather than overall foreseeability.

216 Ehrenzweig disregards foreseeability when the application of the law of the plaintiff's residence is allowed.

217 Ehrenzweig, supra note 177 at 603.

218 Ehrenzweig, supra note 190 at 988.

210 Ehrenzweig, supra note 177 at 603.

220 Note 190 supra.

221 Ehrenzweig, supra note 177 at 603. 
in order to do justice in particular cases. The development of a common law with respect to the specific types of enterprise liability should adequately provide for exceptional circumstances. 222

Althougl the "foreseeable and insurable laws" rule proposed by Ehrenzweig appears to be burdened with faulty terminology, the rule can be reformulated so that it refers to the laws of those states having some "relevant contact" with the case and allows the plaintiff his choice among those laws. ${ }^{223}$ Generally, the states of the plaintiff's and the defendant's residence will be the only states having a "relevant contact" with the case. ${ }^{224}$ It is submitted that Elrenzweig's theory, as reformulated, would reach acceptable results in conflicts cases involving enterprise liability.

\section{CONCLUSION}

The American Law Institute, in an effort to improve upon the first Restatement, which threw the law of conflict of laws into turmoil, lias completed a tentative draft on torts. This draft reflects the views of Professor Reese, the Reporter, and adopts the "most significant relationship" theory, apparently with little, if any, case support. The draft's proposals are enlightened in some respects-they do recognize that compensatory and admonitory torts may require different treatment-but the "most significant relationship" rule is unsuitable as a general rule in tort and contract conflict of laws cases.

The suggested alternatives to the draft's rules-the theories of Professors Currie and Ehrenzweig-also contain problem areas. Both, however, go a long way toward a rational choice of law rule. Both appear to be workable; the "most significant relationship" theory is not. It is suggested, therefore, that the Institute reconsider its proposal with a view to providing the courts with a more feasible rule.

James R. Bridges

William D. Segal

222 Ehrenzweig takes the common law of conflicts law into account in the formulation of his rule. TREATISE $\S 101$ at $308, \S 122$ at 350 .

223 This appears similar to the suggestions originally made by Cook. See Coor, THE LOGICAI AND LEgal Bases OF THE CoNfIICT OF LAWS 345 (1942).

224 Currie concludes that the states of plaintiff's and defendant's residences normally have legitimate interests. See text accompanying note 151 supra. 